\title{
H2AJ Gene
}

National Cancer Institute

\section{Source}

National Cancer Institute. H2A/Gene. NCI Thesaurus. Code C162816.

This gene plays a role in chromosome stability. 